\title{
Политические системы Монгольской Народной Республики и Тувинской Народной Республики в 1930-1940-е гг.: изменения средоточия власти
}

\author{
Иванна В. Отрощенко \\ Институт востоковедения им. А. Е. Крымского \\ Национальной академии наук Украины, \\ украина

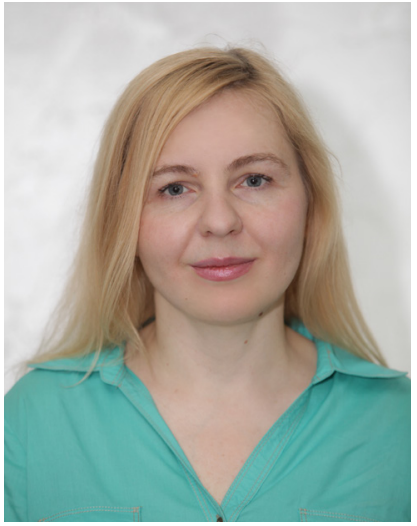 \\ В статье анализируется и сравнивается практика соперничества между премьер- \\ министрами и «генсеками» (1-ми секретарями) в политических реалиях Монгольской \\ Народной Республики и Тувинской Народной Республики 1930-1940-х г2. Исследование \\ базируется на документах, часть из которых остается неопубликованными, в част- \\ ности на материалах РГАСПИ и АВП РФ. \\ Рассматриваются наиболее наглядные, по мнению автора, примеры такого сосу- \\ ществования и конкуренции: с одной стороны, период премьерства П. Гэндэна, а также \\ относительное взаимодействие премьера Х. Чойбалсана и генсека ЦК МНРП Ю. Цэ- \\ дэнбала, сдругой - «эпоха» 1-го (затем генерального) секретаря ЦК ТНРПС. Токи. Борьба \\ за власть проходила в условиях неустойчивой политической конъюнктуры, влияния \\ СССР и Коминтерна и частого наложения одна на другую сфер обязанностей правитель- \\ ства и ЦК партии, прописанных в политических документах и нормативно-правовых \\ актах того времени. По мнению автора, результат такой политической борьбы во \\ многом зависел от силы характера персоналий. Если в МНР премьерам (в первую очередь \\ $X$. Чойбалсану, в меньшей степени и на меньший срок П. Гэндэну) удавалось удерживать \\ в своих руках бразды правления, не уступая партийным функционерам, то в Туве, \\ наоборот, победу одержал 1-й секретарь ЦК ТНРП. Решающим фактором в этих процессах также являлась степень \\ советской поддержки того или иного политика, базировавщаяся, в первую очередь, на лояльности последнего к СССР.
}

Ключевые слова: Монгольская Народная Республика; Тувинская Народная Республика; СССР; МНРП; ТНРП; Коминтерн; премьер-министр; генеральный секретарь; первый секретарь; политическая элита; Пэлжидийн Гэндэн; Хорлогийн Чойбалсан; Юмжагийн Цэдэнбал; Салчак Калбакхорекович Тока

Отрощенко Иванна Витальевна - доктор исторических наук, ведущий научный сотрудник отдела современного Востока Института востоковедения им. А. Е. Крымского Национальной академии наук Украины; главный редактор журнала «Східний світ» («Мир Востока»). Адрес: 01001, Украина, г. Киев, ул. Грушевского, д. 4, к. 226. Эл. адрес: shidnyj.svit@gmail.com

OTROSHCHENKO, Ivanna Vitalievna, Doctor of History, Leading Research Fellow, Department of the Modern East, A. Yu. Krymskyi Institute of Oriental Studies, NAS of Ukraine; Editor-in-Chief, Shìdnij svìt (The World of the Orient). Postal address: Apt. 226, 4 Hrushevskyi St., 01001 Kyiv, Ukraine.Email: shidnyj.svit@gmail.com 


\title{
Political systems of Mongolian People's Republic and Tuvan People's Republic in 1930s and 1940s: changes in the focus of power
}

\author{
Ivanna B. Otroshchenko \\ A. Yu. Krymskyi Institute of Oriental Studies, \\ National Academy of Science, Republic of Ukraine
}

\begin{abstract}
The article examines and compares the rivalry between prime ministers and general secretaries ('genseki') within the political system of the Mongolian People's Republic and Tuvan People's Republic in the 1930s and 1940s. Our study is based on documents, some still unpublished, and others preserved at the Russian State Archive of the Social and Political History and the Foreign Policy Archive of the Russian Federation.

We focus on what seems to be the most conspicuous cases of such rivalry and coexistence. On the one end of the spectrum lies the premiership of P. Genden, and the hesitant collaboration of Prime Minister Kh. Choibalsan and the Secretary General of the Central Committee of Mongolian People's Revolutionary Party Yu. Tsedenbal. On the other, the rule of the First (later General) Secretary of Central Committee of Tuvan People's Revolutionary Party S. Toka. The struggle for power unfurled under unstable political circumstances, under the influence of USSR and the Communist International (Comintern), and with frequent overlaps of responsibilities assigned by the political documents and legal acts of the time to the Cabinet of ministers and the Party's Central Committee. We conclude that the outcome of such political struggle mostly depended on its participants' strength of character. While Mongolian prime ministers (especially Kh. Choibalsan, but for a shorter term and in smaller degree, this is also true for P. Genden) managed to hold the reins, in Tuva the First Secretary was ultimately victorious. Another decisive factor was the degree of support a politician could garner from the USSR - support which largely depended on his loyalty.
\end{abstract}

Keywords: Tuvan People’s Republic; Mongolian People’s Republic; USSR; Mongolian People’s Revolutionary Party; Tuvan People’s Revolutionary Party; Communist International; Prime Minister; General Secretary; political elite; Peljidiin Genden; Khorloogiin Choibalsan; Yumjaagiin Tsedenbal; Salchak Kalbakkhorekovich Toka

For citation:
Otroshchenko I. V. Politicheskie sistemy Mongol'skoi Narodnoi Respubliki i Tuvinskoi Narodnoi Respubliki v
1930-1940-e gg.: izmeneniia sredotochiia vlasti [Political systems of Mongolian People's Republic and Tuvan People's
Republic in 1930s and 1940s: changes in the focus of power]. New Research of Tuva, 2021, no. 3, pp. 15-33. (In Russ.)
DOI: https://www.doi.org/10.25178/nit.2021.3.2

\section{Введение}

Весной 1932 г. в Монгольской Народной Республике (МНР) началось мощное антиправительственное восстание, постепенно охватившее значительную часть страны (больше см.: Кузьмин, Оюунчимэг, 2015). Это событие, а также восстание в Тере-Холе, начавшееся в то же время в Тувинской Народной Республике (ТНР $)^{1}$, заставили советскую сторону пересмотреть свои рекомендации обеим республикам. Среди мер, предложенных советской стороной для нормализации обстановки и вывода обеих обществ из глубокого кризиса, вызванного политикой т. н. «левого уклона», в первую очередь попытками коллективизации, были и такие, что оказали непосредственное влияние на политическую жизнь в Монголии и Туве. Народно-революционные партии должны были хотя бы временно уступить «пальму первенства» исполнительной власти, которую монгольская и тувинская политические элиты провозгласили руководителем всей политической, экономической и культурной жизни в республиках.

В данной работе исследуется эволюция политических институтов МНР и ТНР в 1930-1940-х гг., в частности практика соперничества между премьер-министрами и 1-ми секретарями ЦК партий, а

\footnotetext{
${ }^{1}$ Речь идет о восстании в Туве весной 1932 г., о Хемчикском восстании, имевшем место двумя годами ранее, весной 1930 г. см.: Самдан, 2020.
} 
также влияние на эти процессы со стороны СССР. Сопоставляются политические процессы и борьба за власть между первыми лицами в обеих республиках, выясняются сходство и отличия во властных вертикалях. Насколько известно автору, эта тема ранее не была предметом отдельного исследования, хотя сама проблема т. н. двоевластия отмечалась в ряде публикаций российских исследователей (см.: Рощин, 2005: 123, 130; 2008: 76, 81, 94, 128; История Тувы, 2007: 197-198, 202, 360; Салчак Тока, 2015: $140,484)^{1}$.

Исследование базируется на документах, часть из которых остается неопубликованными, в частности на материалах Российского государственного архива социально-политической истории (далее - РГАСПИ) и Архива внешней политики Российской Федерации (далее - АВП РФ). В работе также используются данные, приведенные в сборниках документов: «Монголия в документах Коминтерна (1919-1934)»²; «Политбюро ЦК РКП(б)-ВКП(б) и Коминтерн. 1919-1943 гг.: Документы»3; «Русский архив: Великая Отечественная» ${ }^{4}$; «Сталин и Каганович. Переписка. 1931-1936 гг.» ; «Документы внешней политики СССР ${ }^{6}$; «Сборник законов и основных постановлений Правительства Тувинской Народной Республики» ${ }^{7}$, а также другие опубликованные документы. Большое значение для исследования также имеют обнародованные интервью, в том числе литературно обработанные, с очевидцами и участниками процессов, происходящих на монгольском Олимпе в середине прошлого века, представленные в изданиях: «Socialist Devotees and Dissenters: Three Twentieth-Century Mongolian Leaders» (Socialist Devotees ... , 2011) и «Цеденбал и его время»8 (Шинкарев, 2006). Из многочисленных работ по монгольской и тувинской истории в ходе данного исследования особый интерес представляют работы, напрямую посвященные монгольским и тувинским политикам и политическим элитам (Рощин, 2005, 2008; Ламажаа, 2010; Салчак Тока, 2015).

Целью исследования является анализ политической борьбы в МНР и ТНР в 1930-1940-х гг. Автор рассматривает соотношение сил в высших эшелонах монгольской власти на примере премьерства П. Гэндэна, а также прецедент относительного взаимодействия премьера Х. Чойбалсана и генсека ЦК МНРП Ю. Цэдэнбала. Когда мы говорим о политических реалиях ТНР, практически весь период исследования припадает на «эпоху» одного человека - 1-го (затем генерального) секретаря ЦК ТНРП С. Токи. Среди задач исследования - сравнить, как протекали процессы, где борьбы, а где противостояния между партийными функционерами и главами правительств в обеих народных республиках, находящихся в фарватере советской политики, проанализировать, какая была степень влияния советской стороны на эти процессы и их результаты. МНР и ТНР, которые были в числе первых, после СССР, социалистических государств, составляя вместе прообраз грядущего социалистического лагеря, имели немало сходных черт в своем политическом развитии, что объяснялось как огромной ролью СССР в их жизни, так и общим историческим прошлым, духовной жизнью и народным хозяйством. Два глубоко традиционных кочевых общества, представляющие тибето-монгольскую цивилизацию, ступившие на путь радикальной социалистической трансформации в первой половине $\mathrm{XX}$ в., со всеми плюсами и минусами этого эксперимента, стали носителями уникального опыта. Тем

\footnotetext{
${ }^{1}$ См. также: Байыр-оол М. С. О государственном перевороте 1938 года // ИА «Тува-онлайн». 24.11.2014. URL: https:/www.tuvaonline.ru/2014/11/24/repressirovannyy-premer-sat-churmit-tazhy-1894-1938.html (дата обращения: 27.11.2018).

${ }^{2}$ Монголия в документах Коминтерна (1919-1934) (2012) / авт.-сост.: И. И. Кудрявцев (отв. сост.) и др. Улан-Удэ. T. II: 1930-1934.

${ }^{3}$ Политбюро ЦК РКП(б)-ВКП(б) и Коминтерн. 1919-1943 гг.: Документы. М. : РОССПЭН, 2004. 958 с.

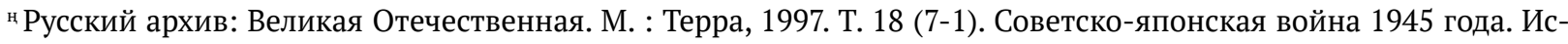
тория военно-политического противоборства двух держав в 30-40-е годы: Док. и материалы. 432 с.

${ }^{5}$ Сталин и Каганович. Переписка. 1931-1936 гг. / сост. О. В. Хлевнюк, Р. У. Дэвис, Л. П. Кошелева, Э. А. Рис, Л. А. Роговая. М. : РОССПЭН, 2001. 798 с.

${ }^{6}$ Документы внешней политики СССР. Т. ХХІІ. 1939. В 2 кн. Кн. 2. Сентябрь-декабрь. М. : Международные отношения, 1992.688 с.

${ }^{7}$ Сборник законов и основных постановлений Правительства Тувинской Народной Республики / под общ. ред. Х. Анчима и С. Т. Чимба. Кызыл : Тувинское государственное издательство, 1944. 456 с.

${ }^{8}$ Автор фундаментального биографического и публицистического сочинения «Цеденбал и его время» (в 2 томах) - Л. И. Шинкарев, советский и российский журналист и писатель, работал корреспондентом «Известий» в МНР в 1977-1981 гг. В основу работы положены, в частности, собранные им интервью со многими действующими лицами «эпохи Цеденбала».
} 
интереснее зафиксировать отличия в формирующейся новой политической традиции, которые, как мы увидим в ходе исследования, имели место в Монголии и Туве, и попытаться выяснить, чем они обусловлены.

\section{Политическая борьба в МНР}

\section{Период премьерства П. Гэндэна}

Еще накануне начала восстания 1932 г. Политкомиссия ИККИ1уверждала, что политика МНР как внутренняя, так и внешняя, должна устанавливаться Центральным Комитетом Монгольской народнореволюционной партии (далее - ЦК МНРП)2. Но уже 16 мая 1932 г. монгольский вопрос обсуждался на заседании Политбюро ЦК ВКП(б) в Москве. Политбюро приняло решение «О Монголии», в котором были утверждены принципы корректировки политического курса в этой стране. 29 мая 1932 г. ИККИ и ЦК ВКП(б) приняли совместное постановление с осуждением «левого уклона», которое было послано в виде письма в ЦК МНРП. Среди основных ошибок, допущенных монгольской властью, первой называли подмену Президиумом ЦК МНРП правительства, превращение последнего в фикцию, сведение на нет правительства и Малого Хурала, что означало не только умаление авторитета, но и полную дискредитацию их в глазах беспартийных масс ${ }^{3}$. Для исправления ситуации предлагалось в частности в кратчайший срок добиться укрепления авторитета правительства как высшего органа власти в республике; поднять авторитет Малого Хурала и обеспечить его работу в соответствии с правами и обязанностями, вытекающими из конституции; обеспечить в его составе до $50 \%$ членов из беспартийных аратов и одновременно усилить выдвижение в правительство и административнохозяйственные органы беспартийных арат и лучших представителей «национально-революционной интеллигенции» ${ }^{4}$ МНРП же рекомендовалось сплачивать широкие народные массы вокруг правительства.

29-30 июня прошел 3-й чрезвычайный пленум ЦК и ЦКК ${ }^{5}$ МНРП, который осудил левый уклон, переизбрал Президиум и секретариат ЦК, принял ряд решений по определению и уточнению функций и разграничения сфер партийной и государственной работы, исходя из положения, что «высшим органом власти в республике является народно-революционное правительство» (РГАСПИ, ф. 508, оп. 3, д. 9, л. 75). Влияние партии должно было обеспечиваться фактом вхождения председателя и членов правительства в Президиум ЦК. Пленум также свел задачи Ревсомола МНР, до того имевшего представительство в правительстве, к работе по воспитанию аратской молодежи, подготовке кадров для партии и исполнению ее поручений (РГАСПИ, ф. 508, оп. 3, д. 9, л. 75).

Такое изменение политической конъюнктуры открывало перед главой исполнительной власти определенные перспективы. 2 июля 1932 г. П. Гэндэн, который ранее был одним из трех секретарей ЦК МНРП, стал премьер-министром МНР. Поскольку ответственность за навязанную советской стороной и Коминтерном губительную политику возложили на МНРП и ее руководство, один из ключевых монгольских политиков того времени и один из лидеров «левого уклона» 3. Шижээ, первый секретарь ЦК МНРП (1931-1932), лишился власти и был отправлен в Москву на учебу. Так тогда советская сторона выводила, как правило, навсегда, подозрительных ей фигур из монгольской политической жизни.

Была проведена основательная чистка МНРП, в результате в партии осталось 11,5 тыс. членов (вместо 42,8 тыс.); партийным организациям запрещалось прямое вмешательство в дела государственных учреждений (Рощин, 2008: 76). П. Гэндэн настаивал на строгом разграничении функций партийных организаций и органов государственной власти, на повышении роли правительства и других властных структур в жизни страны (собственно, как и рекомендовали в 1932 г. советские товарищи). Он говорил на IV пленуме ЦК МНРП (октябрь 1933 г.): «Партия должна помогать проводить в жизнь законы правительства, мобилизовать массы. Решения Совета Министров должны быть обязательны не только для местных органов власти, но и для партийных органов...» (цит. по: там же: 81).

\footnotetext{
${ }^{1}$ ИККИ - Исполнительный комитет Коммунистического Интернационала.

${ }^{2}$ Монголия в документах Коминтерна (1919-1934) / авт.-сост.: И. И. Кудрявцев (отв. сост.) и др. Улан-Удэ, 2012. T. II: 1930-1934. С. 333.

${ }^{3}$ Политбюро ЦК РКП(б)-ВКП(б) и Коминтерн. 1919-1943 гг.: Документы. М. : РОССПЭН, 2004. 958 с. С. 662.

${ }^{4}$ Политбюро ЦК РКП(б)-ВКП(б) и Коминтерн... С. 664.

${ }^{5}$ ЦКК - Центральная контрольная комиссия.
} 
Такое состояние дел, судя по всему, беспокоило новое партийное руководство. В 1933 г. (25 декабря) на встрече со И. В. Сталиным Б. Элдэв-Очир (один из трех секретарей ЦК МНРП) сообщил: в связи с мероприятиями по повышению авторитета власти среди населения и значительным количественным сокращением партии в результате проведенной чистки, у некоторых партийцев создается впечатление, что ныне руководящая роль перешла к правительству и что партия отошла на второй план. Так ли это? Сталин на это ответил, что руководство партии и правительства наверху должно быть единым, внизу же расчленяться на линии партийную и государственную, и партия должна быть прочно связана с населением (РГАСПИ, ф. 558, оп. 11, д. 351, л. 4).

17 сентября 1934 г. Политбюро утвердило делегацию от ВКП(б) и Коминтерна на IX съезд МНРП. Из инструкции делегации ИККИ (23 сентября 1934 г.) следовало, что в результате правильной линии, взятой Пленумом ЦК МНРП в июне 1932 г., хозяйственное положение Монголии за последние два года сильно улучшилось. Поголовье скота увеличилось, улучшилось снабжение основными товарами даже отдаленных аймаков. Государственный аппарат начинает лучше функционировать и авторитет правительства в стране укрепляется. При этом коминтерновцы констатировали упадок работы центральных органов партии и ослабление деятельности партии в массах. Например, Президиум ЦК МНРП провел в 1934 г. не больше 5-6 заседаний, а вступление в партию новых членов прекратилось ${ }^{1}$.

Итак, делегации поручалось подтвердить сохранение в полной силе всех указаний письма ИККИ и ЦК ВКП(б) от 29 мая 1932 г., а также правильность решений июньского Пленума ЦК МНРП как в их политической, так и в организационной части. Делегация должна в дружеской форме указать П. Гэндэну на необходимость полной сработанности правительства и Президиума ЦК МНРП и разъяснить ему, что недоцценка значения и роли партии и партийной работы означала бы серьезную политическую ошибку, чреватую последствиями. В то же время надо было указать секретарям ЦК МНРП, что ЦК не может претендовать на вмешательство в повседневную работу правительства 2.20 сентября 1934 г., комментируя инструкции делегации, Л. М. Каганович писал Сталину следующее: «В организационном вопросе делается ударение на поднятие роли и удельного веса партии, при этом исходить из безусловного сохранения Гендуна»³.

С отчетным докладом ЦК МНРП на IX съезде выступил П. Гэндэн, в частности заметив:

«Я должен подчеркнуть перед вами, что теперешнее наше руководство, партийное и государственное, монолитное, вполне единое. Нет между нами малейшего разногласия, никаких разговорчиков. От первого и II съезда такого единства никогда не было»4.

Коминтерновцы отмечали, что накануне их приезда в Улан-Батор уже был готов политический отчет секретаря ЦК МНРП, который «министр-президент» должен был произнести на съезде. В этом отчете на трех страницах была сформулирована роль партии, но только как «агитпропа правительства». После дискуссии с гостями через день Гэндэн изменил свой взгляд и на съезде уже защищал новую точку зрения о руководящей роли партии.

Б. Шмераль, член исполкома Коминтерна, выступая в прениях по политическому отчету ЦК МНРП, отметил, что во времена «гибельных левацких ошибок» партия командовала всем, а роль правительства почти совершенно исчезла ${ }^{5}$. Но после исправления левых ошибок, особенно в последние месяцы 1933 г. и в течение 1934 г., МНРП очутилась перед другой крайностью: перед аратами выступают только правительство и его органы, а партия и ее организации и комитеты вследствие того, что ослабляют свою работу, начинают терять свое значение. Б. Шмераль акцентировал на том, что Президиум ЦК МНРП в текущем году (1934г.) лишь в виде исключения занимался важными, принципиальными вопросами государственной политики, что не руководил работой высших государственных органов, не проводил регулярных заседаний, что в течение нескольких месяцев этого года вообще не собирался. И отношения между партийными и государственными органами в аймаках не отвечали всегда нормальному положению6. «Как вообще мыслима без права политического руководства

\footnotetext{
${ }^{1}$ Монголия в документах Коминтерна (1919-1934) / авт.-сост.: И. И. Кудрявцев (отв. сост.) и др. Улан-Удэ, 2012. T. II: $1930-1934$. C. 364.

${ }^{2}$ Там же. С. 365.

${ }^{3}$ Сталин и Каганович. Переписка. 1931-1936 гг. / сост. О. В. Хлевнюк, Р. У. Дэвис, Л. П. Кошелева, Э. А. Рис, Л. А. Роговая. М. : РОССПЭН, 2001. С. 488.

${ }^{4}$ Монголия в документах Коминтерна (1919-1934)... С. 371.

${ }^{5}$ Там же. С. 378.

${ }^{6}$ Там же.
} 
государством революционная партия в революционном государстве такого особого типа, как МНР, без такой авторитетной партии не могло бы продолжительное время держаться революционное правительство», - патетически заключил коминтерновский функционер ${ }^{1}$.

Поэтому делегация Коминтерна советовала провести в жизнь принципы, принятые в июне 1932 г., как основы для политики нового курса. Объяснялось, что партия руководит политически, правительство на основе этого политического руководства управляет страной. Члены партии и правительства принимают и осуществляют политическое руководство партии, партия и ее организации не вмешиваются в функции государственного управления, наоборот, делают все, чтобы своей разъяснительной и пропагандистской работой в массах помогать проведению правительственных мероприятий, поддержанию революционной законностиㄹ․ В результате приняли постановление, что Президиум ЦК МНРП должен заседать не менее чем раз в декаду. Секретариат ЦК МНРП в составе трех человек, не являющихся членами правительства, обязан подготавливать порядок дня для заседаний правительства, необходимый материал и контролировать, чтобы члены ЦК, являющиеся членами правительства, проводили решения, которые принимаются в ЦК³.

Вышеупомянутая делегация ИККИ пришла к следующему выводу:

«Самой крепкой и авторитетной фигурой среди руководящих монгольских личностей сегодня неоспоримо является Гендун. Большинство министров и большинство членов Президиума ЦК идет за ним. Его ценят и те из руководителей партии, которые не входят непосредственно в его группу. Мы получили впечатление, что Гендун пользуется популярностью и авторитетом также среди аратских масс, он - сейчас самая популярная фигура в стране. В то же время его отношение к СССР и Коминтерну не такое, чтобы мы могли рассматривать его как дисциплинированного исполнителя любой директивы из Москвы. Он имеет высокое сознание о независимости страны и сильно дорожит своим постом министра-премьера независимого государства» ${ }^{4}$

Среди политиков, которых можно было б противопоставить П. Гэндэну, называли двух секретарей ЦК МНРП - Б. Элдэв-Очира и Д. Лувсаншарава, а также главкома $\mathrm{MHPA}^{5}$ Г. Демида:

«Лубсаншарап первый поставил перед нами в присутствии Гендуна вопрос о руководящей роли партии. <...> Элдэбочир, Демид (коммунист)... прошли через советские школы, говорят по-русски. Эти товарищи вместе с Лубсаншарапом способны защищать нашу точку зрения...»6.

По мнению комиссии, МНРП в целом, в лице всех своих руководителей, всего актива, сама отступила на второй план, отказалась от своей руководящей роли, испугавшись коллективизации, последствий левацкого курса: восстания 1932 г., бегства населения за границу, на китайскую территорию, падения поголовья скотаㄱ. В какой степени партия будет инициативна, в какой степени она будет проводить контроль, зависит не от бумажного постановления, а от живых людей.

В свою очередь, Ш. З. Элиава ${ }^{8}$ также подчеркивал, что во главе правительства МНР оказался человек необычайно энергичный и инициативный, не то что прежний премьер Жигжитжап ${ }^{9}$, о котором говорили,

«что он хороший человек, потому что если 2 русских человека у него сидят в кабинете и они между собой не согласны и ему рекомендуют каждый свое, то он обоих слушается, потому что это советники, но кто прав, он не знает, хотя хочет делать и то, и другое. Он был безличным человеком, но он был послушным орудием. Теперь появился председатель правительства [Гендун], который не только не слушает, но хочет сам сказать решающее слово, а партруководство более слабое» ${ }^{10}$.

\footnotetext{
${ }^{1}$ Монголия в документах Коминтерна (1919-1934) / авт.-сост.: И. И. Кудрявцев (отв. сост.) и др. Улан-Удэ, 2012. T. II: 1930-1934. C. 379.

2 Там же.

${ }^{3}$ Там же. С. 392-393.

${ }^{4}$ Там же. С. 382.

${ }^{5}$ МНРА - Монгольская народно-революционная армия.

${ }^{6}$ Монголия в документах Коминтерна (1919-1934)... С. 382.

7 Там же. С. 383, 392-393.

${ }^{8}$ Ш. З. Элиава - член Монгольской комиссии ПБ ЦК ВКП(б), заместитель наркома внешней торговли, был послан в МНР для руководства проведением политического курса, намеченного в Москве в связи с восстанием 1932 г.

${ }^{9}$ Ц. Жигжиджав - премьер-министр МНР с 1930 по 1932 г.

${ }_{10}$ Монголия в документах Коминтерна (1919-1934)... С. 407-408.
} 
Ш. Элиава заключил, что, по его мнению, и председателя правительства, и секретаря партии нужно воспитывать.

На встрече со Сталиным 15 ноября 1934 г. Гэндэн вернулся к вопросу о «руководстве» МНР, повторив, что «Единство руководства у нас на лицо. Принципиальных разногласий нет» (РГАСПИ, ф. 558, оп. 11, д. 351 , л. 31). Он признал, что недавний съезд отметил слабое руководство со стороны ЦК партии правительством и сказал, что в этом вина не только секретарей ЦК, но и его, как члена Президиума ЦК МНРП. Во время беседы Гэндэн старался добиться ответа, согласна ли советская сторона с его словами о единстве в руководстве (РГАСПИ, ф. 558, оп. 11 , д. 351 , л. 35). Сталин в ответ призвал всячески укреплять единство, назвав это основным условием успешной работы.

Тем не менее, после IX съезда МНРП позиции премьера начали постепенно слабеть на фоне усиливающейся активности партийных функционеров (Рощин, 2008: 94). Так, в частности Д. Лувсаншарав постоянно пререкался с Гэндэном, следил за ним, подвергал его открытой критике и тайно писал на него доносы; по мнению известного монгольского публициста и общественно-политического деятеля Б.-Э. Батбаяра, между ними был конфликт и личного характера (Баабар, 2010: 380).

Однако гораздо более опасным для власти П. Гэндэна было возраставшее недовольство по отношению к нему советской стороны. 27 августа 1935 г. Каганович сообщал Сталину: «От Таирова ${ }^{1}$ из Монголии получилось интересное письмо, в котором он рассказывает о настроениях Гендуна и всей верхушки. Видимо, Гендун все больше отходит от нас»². Во время встречи с монгольской делегацией 30 декабря 1935 г. Сталин указал, что главным вопросом для МНР в настоящее время является вопрос об обороне и тот факт, что правительство МНР из бюджета в 32 млн тугр. отпускает монгольской армии только 8 млн, то есть около одной четверти бюджета, говорит о том, что монгольское правительство не хочет защищать независимость Монголии. Гэндэна упрекнули в отсутствии достаточного интереса к пограничным инцидентам и переговорам на ст. Маньчжурия и в том, что монгольский премьер считает их делом не Маньчжоу-Го и МНР, а СССР и Японии. Сталин также сказал, что Гэндэн не ведет борьбу против ламства и не понимает, что ламство есть враг МНР: «У вас, т.т. Гендун и Намсарайㄱ, нет аппетита борьбы с ламством. Когда кушаешь, надо кушать с аппетитом» (РГАСПИ, ф. 558, оп. 11, д. 351, л. 97).

Напомнили премьеру и то, что он часто ругает СССР, особенно, когда выпьет. В. Молотов сказал:

«...вы, Гендун, в пьяном виде все время говорили антисоветскую провокацию. Мы знаем, что вы пред отъездом сюда говорили, что, наверно, мне через кремлевскую больницу предложат долгосрочный отпуск и отдых в Крыму “по состоянию здоровья”. Мы не собираемся делать такую махинацию и заниматься такой игрушкой» (РГАСПИ, ф. 558, оп. 11, д. 351, л. 91).

Гэндэн оправдывался, что монгольский бюджет невелик и поэтому было решено дать на армию не больше 8 млн тугр. Но он понимает необходимость защиты независимости МНР, возможные последствия японской оккупации и необходимость помощи СССР в деле укрепления независимости Монголии, всегда «был, есть и будет» за помощь Советского Союза. Согласился монгольский премьер и с обвинением в недостаточности борьбы против ламства и пообещал ее усилить. Что же касается слов о том, что его из Москвы пошлют в Крым, то он таких вещей никогда не говорил, и это «походит на сон» (РГАСПИ, ф. 558, оп. 11, д. 352, л. 13). Советское руководство он не убедил.

На 2-м пленуме ЦК МНРП (11-20.03.1936) П. Гэндэна, помимо всего прочего, обвинили в попытках принизить руководящую роль партии (Рощин, 2008: 128). Официальное освобождение П. Гэндэна от обязанностей премьер-министра и министра иностранных дел состоялось на 20-й сессии Малого хурала 22 марта 1936 г. Далее его отправили на лечение в СССР, в Крым, как он когда-то и опасался. Как известно, в 1937 г. он был арестован в Сочи и казнен через несколько месяцев.

\section{Период премьерства Х. Чойбалсана}

Старожил монгольской политики Х. Чойбалсан стал премьер-министром МНР 22 марта 1939 г., оставаясь при этом министром внутренних и иностранных дел, военным министром, главкомом. Х. Чойбалсан считался одновременно и первым руководителем МНРП, хотя не занимал в партийном аппарате ключевого поста (Надиров, 1995: 23) (вышеупомянутый Д. Лувсаншарав, остававшийся одним из трех секретарей ЦК МНРП, был арестован в июле 1939 г.). Предшественник Чойбалсана на

\footnotetext{
${ }^{1}$ В. Х. Таиров - в 1935-1937 гг. полпред СССР в Монголии.

${ }^{2}$ Сталин и Каганович. Переписка... С. 537.

${ }^{3}$ Д. Намсрай - начальник Государственной внутренней охраны MHР.
} 
посту премьера (А. Амар), как и подавляющее большинство политической и военной элиты МНР, пали жертвами политических репрессий. Ответственность за их гибель во многом лежала и на новом премьере, который возглавлял МВД МНР и поддержал советскую инициативу по поиску врагов внутри собственной страны ${ }^{1}$.

3 декабря 1939 г. Чойбалсан, во время встречи в Москве с В. Г. Деканозовым², дав краткую характеристику состояния партии, пришел к выводу, что МНРП серьезно ослабла политически и организационно 3 . 3 января 1940 г. на встрече с советским руководством Х. Чойбалсан представил Сталину Ю. Цэдэнбала, министра финансов МНР, входившего в состав монгольской делегации. Тут мы вернемся немного назад. Еще в марте 1939 г. в МНР прибыла новая группа оперативников советской разведки во главе с И. А. Ивановым, который стал новым полпредом СССР в МНР ${ }^{4}$ и который, по мнению К. Этвуда, и рекомендовал Цэдэнбала Чойбалсану (Atwood, 2004: 104). В марте 1939 г. Ю. Цеденбал стал заместителем министра финансов МНР. В апреле 1940 г. молодой человек, который лишь в 1939 г. вступил в правящую партию, был избран генеральным секретарем ЦК МНРП.

Как справедливо отмечают некоторые исследователи, Ю. Цэдэнбал начал свою политическую карьеру длиной в жизнь в качестве генерального секретаря партии в нежном возрасте 23 лет, поскольку его преданность Советскому Союзу была очевидной и непоколебимой (Myadar, 2017: 17). С другой стороны, коллега Цэдэнбала Б. Нямбуу, член ЦК МНРП, признавал, что в то время в Монголии не хватало профессиональных кадров, особенно после политических репрессий конца 1930-х гг. Молодых профессионалов в области финансов и экономики, владеющих русским языком, таких как Цэдэнбал, было довольно мало (Socialist Devotees ..., 2011: 201).

Из записи беседы В. Деканозова с Ю. Цэдэнбалом, имевшей место 18 марта 1943 г., мы узнаем обстоятельства назначения последнего на высокую должность, роль в этом назначении советской стороны, «благосклонность», о которой не давали забыть: «В разговоре с Цеденбалом мы вспомнили как на приеме Чойбалсана у тов. Молотова В.М. в янв. 1940 г., на котором присутствовал и тов. Сталин - была намечена его (Цеденбала) кандидатура на пост секретаря ЦК МНРП, когда он был министром финансов МНР, недавно окончившим Иркутский Финансово-экономический институт. Цеденбал ответил, что это он хорошо помнит» (АВП РФ, ф. 06, оп. 5, д. 40, п. 4, л. 16)5. В заключение В. Деканозов сказал Ю. Цэдэнбалу, что в Москве его знают, как способного, пользующегося уважением и доверием руководящего товарища в Монголии. Во время беседы присутствовали советник ЦК МНРП Ю. К. Приходов и Г. П. Латышев ${ }^{6}$ (АВП РФ, ф. 06, оп. 5, д. 40, п. 4, л. 16). К фигуре Ю. Приходова мы вернемся далее. Б.-Э. Батбаяр заметил схожесть ситуации с двумя монгольскими премьерами и прокомментировал представление Цэдэнбала советскому руководству так:

«Было ли это велением судьбы? Годами раньше на встрече премьер-министра Гэндэна со Сталиным, по указке русских, присутствовал непосредственно Чойбалсан, который вышел из кабинета уже заместителем премьера ${ }^{7}$. Но Чойбалсан отправил Гэндэна на тот свет. А сейчас неужели пришла очередь его самого?» (Баабар, 2010: 375).

\footnotetext{
19 февраля 1939 г. Х. Чойбалсан сообщил заместителю полпреда СССР в МНР А. С. Скрипко, что он получил указание Сталина: «удалить из правительства МНР Амора и пост премьер-министра принять на себя, сохранив за собой посты военного министра, министра внутренних и иностранных дел, подобрав себе по этим министерствам новых заместителей из числа политически надежных и ничем не скомпрометированных людей <...> Чойбалсан сообщил далее тов. Скрипко, что перед его отъездом из Москвы тов. Ворошилов передал ему дополнительное указание тов. Сталина: провести отстранение Амора от руководства правительства МНР через секретаря ЦК МНРП Лубсан Шарапа» (см.: Русский архив: Великая Отечественная. М. : Терра, 1997. Т. 18 (7-1). Советско-японская война 1945 года. История военно-политического противоборства двух держав в 30-40-е годы: Док. и материалы. С. 113).

${ }^{2}$ В. Г. Деканозов - заместитель наркома иностранных дел СССР (1939-1947). В его ведении был ряд азиатских стран, в частности Монголия.

${ }^{3}$ Документы внешней политики СССР. T. XXII. 1939. В 2 кн. Кн. 2. Сентябрь-декабрь. М. : Международные отношения, 1992. С. 361.

${ }^{4}$ И. А. Иванов (1906-1948) - советский военный деятель и дипломат; полномочный представитель (до 9 мая 1941 г.), посланник (с 9 мая 1941 г.) СССР в МНР.

${ }_{5}^{5}$ Ознакомиться с некоторыми делами АВП РФ стало возможным благодаря масштабному проекту: СССР и союзники. Документы Архива МИД России о внешней политике и дипломатии ведущих держав антигитлеровской коалиции. URL: http://agk.mid.ru/ (дата обращения: 25.10.2020).

${ }^{6}$ Г. П. Латышев - глава 3-го Дальневосточного отдела МИД СССР.

${ }^{7}$ Имеется в виду встреча П. Гэндэна и Х. Чойбалсана с советским руководством, которая состоялась в Москве 15 ноября 1934 г. На ней Гэндэн сообщил, что Чойбалсан рекомендуется на пост первого заместителя премьерминистра.
} 
На пленуме ЦК МНРП в конце 1943 г. было принято решение упразднить Президиум ЦК МНРП и создать Политбюро и Секретариат ЦК МНРП. В Политбюро ЦК МНРП вошли: Х. Чойбалсан, Ю. Цэдэнбал, Ч. Сурэнжав, Г. Бумцэнд и С. Янжма. Ю. Цэдэнбал снова был избран генеральным секретарем, а Ч. Сурэнжав стал 2-м секретарем ЦК МНРП.

При премьере Х. Чойбалсане генеральный секретарь ЦК МНРП Ю. Цэдэнбал был вторым лицом в государстве и не имел решающего голоса. Как отмечал Б. Нямбуу (возможно субъективно), Цэдэнбал «стал известным только после Чойбалсана» (Socialist Devotees ..., 2011: 199). Встречается также такое определение их политического взаимодействия как дуумвират (см.: Dillon, 2020: 106). В частности, именно премьер-министр Х. Чойбалсан выступал с политотчетами ЦК на X и ХI съездах партии, не будучи секретарем ЦК МНРП, как в свое время П. Гэндэн (Рощин, 2008: 84). Например, и на вышеупомянутом пленуме ЦК МНРП Чойбалсан выступал с докладом о состоянии животноводства в МНР и задачах партийных организаций, тогда как Цэдэнбал докладывал об организационных вопросах (АВП РФ, ф. 06, оп. 5, д. 297, п. 26, л. 19).

Премьер-министр и генеральный секретарь партии довольно успешно взаимодействовали на протяжении ряда лет. К примеру, 24 декабря 1942 г., в беседе с В. Деканозовым, Х. Чойбалсан, касаясь политического состояния страны, характеризовал его устойчивым и дал высокую оценку новым кадрам. Он заявил: «Обыкновенно я при приездах в Москву раньше ставил вопросы о людях, мешающих работать, - теперь я ни на кого не жалуюсь. В ЦК и в правительстве хорошие кадры и работают дружно» (АВП РФ, ф. 06, оп. 5, д. 40, п. 4, л. 116).

Но со временем определенные расхождения начали четче проявляться: инициативы Цэдэнбала о присоединении МНР к СССР и кооперировании аратских хозяйств, которые Чойбалсан, дороживший независимостью Монголии и помнивший предыдущую попытку коллективизации, закончившуюся восстанием 1932 г., не поддерживал. По словам С. К. Рощина, взгляды обоих политиков также не полностью совпадали в вопросах идеологии и в отношении к национальному наследию, традициям (Рощин, 2005: 130). Эта дискуссия имела свое продолжение, в частности в 1960-х гг.: так, многие монгольские интеллектуалы полагали, что быстрая модернизация разрушает национальные традиции, тогда как Цэдэнбал и его сторонники считали культурное наследие Монголии фактором, существенно сдерживающим развитие страны (Szalontai, 2005: 94).

«Чойбалсан относится с большим подозрением к росту других “авторитетов” в МНР. Поэтому он недооценивает значения коллегиального руководства страной, чем помимо его воли задерживается рост новых руководящих кадров. Исключение в этом отношении составляет только Цеденбал, которого Чойбалсан искренне уважает и считает своим воспитанником и преемником», - писал в августе 1949 г. посланник СССР в МНР Ю. К. Приходов (РГАСПИ, ф. 82, оп. 2, д. 1280, л. 20).

В вопросах, разделяющих обоих политиков (о присоединении МНР к СССР и кооперировании аратских хозяйств), советский дипломат был на стороне премьера. Но в уже процитированном донесении секретарю ЦК ВКП(б) Г. М. Маленкову Ю. К. Приходов намекал на «факты излишеств, к которым склонен Чойбалсан, в основе которых лежит все та же болезнь “вождизма”» и добавлял, что эти недостатки Чойбалсана заслуживают внимания (РГАСПИ, ф. 82, оп. 2, д. 1280, л. 20). Он также опасался, что настроения маршала в отношении Внутренней Монголии вызовут нежелательные последствия (РГАСПИ, ф. 82, оп. 2, д. 1280, л. 17-19; больше см. также: Отрощенко, 2010). В то же время Приходов признавал, что руководящая роль Чойбалсана в республике и монгольской партии несомненна: «Он пользуется настоящим непререкаемым авторитетом среди самых широких слоев аратства, всего населения МНР и в партии. Политические убеждения Чойбалсана и его искренность в отношении к Советскому Союзу не вызывают сомнений» (РГАСПИ, ф. 82, оп. 2, д. 1280, л. 16). Тем не менее, хотя большую часть своей карьеры Чойбалсан зависел от советов из Москвы, после 1945 г. он «начал проявлять признаки независимости и даже национализма ${ }^{1}$ (Christian, 2018: 426).

С. К. Рощин, известный исследователь политических элит МНР, подчеркивал доверительность и теплоту отношений между этими премьером и генсеком (Рощин, 2005: 123). Однако Л. И. Шинкарев, написавший свое фундаментальное сочинение о Цэдэнбале на основании широкого круга источников, упоминает следующее: «На конфиденциальных встречах в советском посольстве, где его принимали

\footnotetext{
${ }^{1}$ Нужно отметить, что Чойбалсан всегда был патриотически настроен, что проявлялось время от времени на протяжении всей его длительной по тем меркам и обстоятельствам политической карьеры. Например, он был среди тех политиков МНР, кто активно поддерживал Баргинское восстание 1928 г.
} 
почти как первое лицо, Цеденбал и его друг Сурэнжав, секретарь ЦК партии, повторяли, что причина долгого топтания страны на месте - беспомощность правительства, давно выпавшего из быстро несущейся вперед повозки времени. Оба недвусмысленно намекали на маршала, на утрату им чувства нового, на его “костенение”, тормозящее практическую работу» (Шинкарев, 2006: 67-68). Видимо, осведомленный о такой активности молодых управленцев, Чойбалсан хотел «убрать подальше от себя» Сурэнжава и пытался рекомендовать последнего на пост посланника в Китай (РГАСПИ, ф. 558, оп. 11, д. 352, л. 89). Осознавая, что встретит сопротивление этой инициативе со стороны самого Сурэнжава, а также недовольство в аппарате ЦК МНРП, он пытался заручиться поддержкой Сталина в этом вопросе (во время их беседы 22 февраля 1946 г.), но безуспешно.

Л. И. Шинкарев полагает, что некоторые советские дипломаты даже были готовы поддержать Цэдэнбала в его амбициях: «Иванов и Приходов ставили на Цеденбала» (Шинкарев, 2006: 69; больше см.: 66-69, 86). По видимому, речь идет о 1946 г. ${ }^{1}$ По словам Б.-Э. Батбаяра, «полномочный представитель Советского Союза Иванов, прибывший в 1939 году... близкую дружбу водил с Цеденбалом» (Баабар, 2010: 388). Взаимоотношения советника ЦК МНРП Ю. К. Приходова и монгольского премьера иллюстрирует записка Л. П. Берии В. М. Молотову от 14 июня 1940 г. Берия сообщал, что по полученным из Улан-Батора сведениям Приходов проявляет по отношению к монгольским руководителям «элементы командования» и успел скомпрометировать себя в глазах последних рядом нетактичных поступков. «Заметно охладел к Приходову и Чойбалсан потому, что Приходов предложил ЦК принять ряд решений, не поставив в известность Чойбалсана и, когда последнему были сообщены эти решения, он был очень возмущен этим» (РГАСПИ, ф. 82, оп. 2, д. 1278, л. 35). Эта цитата также свидетельствует о том, что несмотря на то, что Ю. Цэдэнбал уже стал генеральным секретарем, Х. Чойбалсан продолжал курировать ЦК МНРП. Л. Берия также указывал, что Чойбалсан очень ревниво оберегает «свое право руководителя МНР», а Приходов это не всегда учитывает. По словам наркома внутренних дел, «характерным для Приходова является его порывистость и стремление вмешиваться в разрешение разного рода вопросов, в которых он недостаточно компетентен» (РГАСПИ, ф. 82, оп. 2, д. 1278, л. 36).

Похоже, кульминационным моментом попыток изменить существующий политический расклад в МНР стало составление Ю. К. Приходовым и Ю. Цэдэнбалом секретного письма советскому руководству на 36-ти страницах. В нем критиковали маршала и его окружение «за склонность выдвигать на высокие посты “своих людей”, за невнимание к молодым, за другие грехи, о которых уже раньше писал в своих отчетах советский посол. <..> На письме решили оставить подпись одного Цеденбала» (Шинкарев, 2006: 86). Некоторое время спустя, в присутствии советских дипломатов Чойбалсан дал понять, что он прекрасно осведомлен о содержании этого письма².

Монгольский премьер, похоже, воспринимал выпады партийных функционеров достаточно спокойно, будучи уверен в поддержке И. Сталина. Интересно объясняет факт такой поддержки востоковед, историк-международник С. Радченко. Он полагает, что Сталин никогда не отказывался от Чойбалсана, отчасти потому, что до последнего не хотел сбрасывать со счетов карту Внутренней Монголии (Radchenko, 2012: 31). По мнению некоторых исследователей, в 1945-1948 гг. Советский Союз поддерживал во Внутренней Монголии планы воссоединения с MHP (Stolberg, 1997: 129). Так, в 1944 г. на встрече в Кремле, где кроме Сталина и Чойбалсана присутствовали В. Молотов, Г. Маленков, Л. Берия, А. Микоян и посол И. Иванов, Сталин назвал Чойбалсана лидером не только Внешней Монголии, но и Внутренней Монголии ${ }^{3}$. Как известно, во время вышеупомянутой беседы Сталина с Чойбалсаном 22 февраля 1946 г. последний, в частности, получил согласие советского лидера на негласную пропагандистскую работу среди монголов Внутренней Монголии и Объединенной Хинганской провинции ${ }^{4}$ (РГАСПИ, ф. 558, оп. 11, д. 352, л. 88). В 1947 г., на даче на озере Рица, куда Х. Чойбалсан прибыл для лечения и отдыха,

${ }^{1}$ В 1947-1948 гг. Ю. К. Приходов находился уже на должности заведующего Отделом Юго-Восточной Азии МИд СССР. И. А. Иванов завершил свою дипломатическую деятельность в МНР 9 октября 1947 г.

${ }^{2}$ Эта история, насколько можно понять, стала известна Л. Шинкареву благодаря интервью, которое он взял у советского дипломата С. С. Дашьяна в 1990 г. (см.: Шинкарев, 2006: 86).

3 "Stalin's Conversation with Choibalsan," January 22, 1944 / Lkhamsurengiin Bat Ochir, “Stalin, Choibalsan naryn 1940-uud ony uulzaltuud”, Khudulmur, No 148. pp. 166-167. Original Translated by Sergey Radchenko // History and Public Policy Program Digital Archive. Wilson Center. URL: https://digitalarchive.wilsoncenter.org/document/209765 (дата обращения: 20.01.2021).

4 Чойбалсан считал необходимым «готовить монгольское население к отделению монгольских территорий от Китая, к созданию монгольского независимого государства» (РГАСПИ, ф. 558, оп. 11, д. 352, л. 88). 
И. Сталин завершил неофициальный обмен мнениями по монгольским делам провозглашением тоста за объединение всех монголов под предводительством маршала Чойбалсана (Atwood, 1999: 157). 11 июля 1947 г. на территории автономного правительства Внутренней Монголии появилась газетная статья на монгольском языке, в которой рассказывалось об этапах карьеры Х. Чойбалсана. Заканчивалась она словами: «10 августа 1945 года была объявлена война японским фашистам (вместе с СССР), и Чойбалсан несколько дней сражался на стороне Красной Армии. Япония была разрушена, монголы Внутренней Монголии были освобождены, и таким образом, Чойбалсан занял почетное положение “Мессии” для всех монголов» ${ }^{1}$.

На ХІ съезде МНРП (8-23 декабря 1947 г.) отмечался рост числа ее членов до 28 тысяч, и признавалось, что нескончаемый поток совместных решений приводит к стиранию граней между партией и государственным аппаратом, к подмене госаппарата партией и к превращению парторганизации в придаток госаппарата. В том числе в целях изживания этих недостатков ЦК МНРП принял решение об увеличении числа заместителей премьер-министра и утвердил 2-го секретаря ЦК МНРП Ч. Сурэнжава первым заместителем Чойбалсана (История Монголии ..., 2007: 183-184). Ч. Сурэнжав, даже перейдя в исполнительную власть, остался верным своим привычкам и продолжал, в частности, критиковать премьера. Так, он часто «напрашивается на “доверительные” беседы, в которых он... охотно говорит о националистических настроениях других, о том, что в МНР не ведется борьба с проявлениями национализма, делает прозрачные намеки, а иногда и прямые заявления по адресу Чойбалсана, который якобы является националистом и проявляет диктаторские наклонности в руководстве республикой, не считается с ЦК МНРП, принижает роль ЦК МНРП и т. д.», - писал в августе 1949 г. Ю. К. Приходов (РГАСПИ, ф. 82, оп. 2, д. 1280, л. 10). Через 10 лет, в марте 1958 г. на ХІІІ съезде МНРП Д. Дамба, 1-й секретарь ЦК, в чем-то повторит такие обвинения, отмечая, что культ личности Х. Чойбалсана привел к грубым нарушениям «революционной законности» и снижению роли партии. К самому Ч. Сурэнжаву советская сторона относилась с подозрением, полагая, что тот «не всегда правильно понимает политику СССР в отношении МНР, считая, что иногда Советский Союз преследует свои цели и недостаточно считается с интересами МНР» (РГАСПИ, ф. 82, оп. 2, д. 1280, л. 34).

После смерти Х. Чойбалсана в 1952 г. Ю. Цэдэнбал получает всю полноту власти, занимая пост премьер-министра МНР и одновременно сохраняя должность генерального секретаря ЦК МНРП. В апреле 1954 г. он оставляет пост генсека и на протяжении нескольких лет в качестве премьера сражается за лидерство с новым 1-м секретарем МНРП, вышеупомянутым Д. Дамбой. В фокусе их полемики остается вопрос кооперирования аратских хозяйств, добавляются и новые проблемы: вопрос о политических репрессиях в МНР и культе Х. Чойбалсана, демаркация границы между Монголией и СССР в конце 1950-х гг. (больше см.: Отрощенко, 2021). В конце концов, Цэдэнбалу удалось заручиться согласием Москвы на ротацию в монгольских властных кругах. После его поездки в Москву (где в конце октября 1958 г. монгольский премьер успел пообщаться с Н. С. Хрущевым) ЦК МНРП собирается на пленарное заседание, по итогам которого Цэдэнбал снова становится 1-м секретарем правящей партии. Эту должность он уже не выпускал из своих рук, сохраняя ее до августа 1984 г.

Анализ событий в МНР в период 1930-1940-е гг. показывает наличие постоянной борьбы между премьерами и секретарями ЦК МНРП. Непременным сопутствующим обстоятельством такой борьбы выступал фактор советских представителей в Монголии - полпредов (затем послов); они пользовались громадным влиянием на политические процессы в стране, их поддержка того или иного представителя монгольской политической элиты много значила. Корни противостояния, помимо борьбы за власть, крылись и в роли представителей Коминтерна в МНР вплоть до середины 1932 г., у которых также были свои «фавориты» среди монгольских политиков и выразительный акцент на роли МНРП в жизни монгольского общества. Даже когда представители Коминтерна перестали назначаться в МНР, секретари ЦК МНРП продолжали помнить их риторику о доминирующем влиянии партии на все процессы в государстве и время от времени использовали ее в борьбе с оппонентами из исполнительной ветви власти. В свою очередь советская сторона была готова, в случае необходимости, использовать секретарей ЦК МНРП в политической борьбе с неугодными ей монгольскими премьерами.

Тем не менее, к концу 1930-х гг. в политической системе МНР именно премьер-министр становится центральной фигурой, обладающей всей полнотой власти в стране. В то же время такие премьеры как

${ }^{1}$ Rise to power of marshal Choibalsan. September 24, 1948 // CIA. URL: https://www.cia.gov/readingroom/docs/CIARDP82-00457R001801100002-1.pdf (дата обращения: 20.01.2021). 
П. Гэндэн и Х. Чойбалсан фактически перенимали часть прерогатив секретарей ЦК МНРП. Традиция выступления премьеров с политотчетами ЦК на партийных съездах и пленумах, фактическое курирование ими ЦК, несмотря на наличие 1-го или генерального секретарей, показывает, что они прекрасно отдавали себе отчет, что высшее партийное руководство является мощным в условиях советской поддержки центром влияния и старались использовать партийные саммиты для демонстрации своей ведущей роли в управлении государством. Конец противостоянию премьеров и секретарей ЦК МНРП в монгольской традиции положил Ю. Цэдэнбал, сосредоточивший к концу 1950-х гг. обе ключевые должности в своих руках.

\section{Партия и правительство в политической жизни ТНР}

Роль высших партийных чинов в политической жизни ТНР начала стремительно возрастать с конца 1920-х гг. Высшим органом государственной власти ТНР являлся Великий хурал - парламент, ответственный за установление основных принципов внешней и внутренней политики (по ст. 16 Конституции ТНР 1941 г.). Исполнительная власть в Туве принадлежала правительству, избранному Малым хуралом, и президиуму последнего ${ }^{1}$. Советский полномочный представитель в ТНР Н. В. Попов в своем письме от 1 августа 1932 г. утверждал, что в Туве, как и в МНР, наблюдались уменьшение роли власти и Малого Хурала, подмена их решений решениями ЦК Тувинской народно-революционной партии (далее - ТНРП) ${ }^{2}$ (РГАСПИ, ф. 508, оп. 3, д. 11, л. 11). По словам полпреда, «в течении 1,5 лет не собирали сессии Хуралдана несмотря на наши указания, только после настойчивых мероприятий с нашей стороны, два месяца тому назад была проведена сессия Малого Хуралдана» (РГАСПИ, ф. 508. оп. 3, д. 11, л. 12 об). Советская сторона, чтобы исправить эту ситуацию, советовала, в том числе, провести перевыборы органов власти с привлечением в органы управления беспартийных аратов, одновременно поднимая авторитет власти и Малого Хурала (РГАСПИ, ф. 508, оп. 3, д. 11, л. 13) рекомендации, аналогичные тем, которые получила монгольская политическая элита.

1 сентября 1932 г. заместитель наркома иностранных дел СССР Л. Карахан писал И. Сталину следующее: народного правительства в Туве фактически не существует, и здесь оно, также как и в Монголии, превращено в орган, штампующий решения ЦК и представителя Исполкома Коминтерна «(там находится постоянный представитель ИККИ - т. Метц)» (РГАСПИ, ф. 508. оп. 3, д. 11, л. 5). В целях ликвидации существующего положения и предупреждения возможных осложнений он считал необходимым поручить Монгольской комиссии ЦК ВКП(б) разработать с учетом работы, проделанной в отношении Монголии, ряд практических мероприятий в направлении исправления ошибок ТНРП на основе следующих положений:

1. Указать тувинским товарищам, что их основная ошибка заключается в том, что они слепо копируют политику СССР, не понимая, видимо, что последний является социалистическим государством, с развитой промышленностью и пролетариатом, тогда как Тува - народно-революционная демократическая республика;

2. Тувинское руководство неправильно ориентирует партию декларированием окончания антифеодального этапа революции и вступления революции в новый этап развития, характеризующийся созданием, якобы, социалистических форм хозяйства;

3. Из этих основных ошибок вытекает политика сплошной коллективизации, неприемлемая для Тувы, фактическое вытеснение частной торговли и монополия Тувинценкопа, вытеснение капиталистических элементов в сельском хозяйстве, фактическая ликвидация правительства и т. д.;

4. ТНРП взяла неправильную установку на превращение себя в пролетарско-бедняцкую партию, в результате чего ЦК ТНРП и правительство оторвались от своей классовой опоры - трудовых аратских масс и оттолкнули зажиточное аратство и часть середняков в сторону феодалов и контрреволюционного ламства;

\footnotetext{
${ }^{1}$ Больше про функции Малого Хурала см.: Сборник законов и основных постановлений Правительства Тувинской Народной Республики / под общ. ред. Х. Анчима и С. Т. Чимба. Кызыл : Тувинское государственное издательство, 1944. С. 18-20, 27-31.

${ }^{2}$ Также полпред отмечал ставку на форсированный перевод с начальных форм коллективизации на сельскохозяйственную артель, механическое перенесение форм и методов работы в СССР (организация колхозной торговли и пр.), неправильное лишение избирательных прав; неправильное проведение налоговой политики, имевшие место в Туве, как и в МНР (РГАСПИ, ф. 508. оп. 3, д. 11, л. 11).
} 
5. Игнорируется то обстоятельство, что среди огромного большинства аратства и даже членов партии еще сильны религиозные предрассудки. Серьезная политико-просветительная и воспитательная работа подменялись издевательствами над религиозными предрассудками народа и борьбой со всем духовенством (РГАСПИ, ф. 508, оп. 3, д. 11, л. 5).

Неделею позже Карахан подчеркивал: «Письмо тов. Попова лишний раз подтверждает необходимость распространения на Туву тех принципиальных решений, которые были приняты ПБ $29 . V$. с. г. в отношении Монгольской Народной Республики» (РГАСПИ, ф. 508, оп. 3, д. 11, л. 11). Далее в Туве, по примеру МНР, хотя и с большой задержкой, если сравнивать с процессами в МНР, решением III чрезвычайной сессии Малого Хурала (28 октября -3 ноября 1933 г.) приступили к т. н. «новому курсу». Эта политика предполагала своеобразную политическую «оттепель» с коррекцией и смягчением внутренней политики во избежания новых народных волнений ${ }^{2}$.

ТНРП была вынуждена признать, что

«погналась за дутыми процентами коллективизации, принудительное вступление членов АРП ${ }^{3}$ и $\mathrm{PCM}^{4}$ в колхозы, налоговая и кредитная политика не только не способствовали развитию частнохозяйственной инициативы, но, наоборот, вытесняли эту инициативу <..> лишение избирательных прав <...> даже трудовых аратских масс, ограничение свободно-рыночных отношений в стране <...> все эти левацкие ошибки привели в результате к упадку производительных сил страны» (РГАСПИ, ф. 495, оп. 16, д. 61, л. 124):

в результате ТНР за период с 1930 до 1933 г. потеряла 72163 головы скота (т. е. снижение поголовья на 7,5\%) (РГАСПИ, ф. 495, оп. 16, д. 61, л. 124).

Решением II чрезвычайного объединенного пленума ЦК и ЦКК ТНРП 23 октября 1933 г. было постановлено: «вся государственная и хозяйственная власть в стране принадлежит правительству <...> отсюда хозяином страны является национально-революционное правительство» (РГАСПИ, ф. 495, оп. 16, д. 61, л. 13). Парторганизации обязывались, не подменяя функций органов власти, через своих партийцев мобилизовать массы на выполнение хозяйственно-политических задач правительства и в этом отношении партия провозглашалась «помощником национально-революционного правительства».

В ТНРП прошла чистка и сокращение рядов по примеру монгольских коллег. За период 1932/1933 г. из партийных рядов «было вычищено в порядке самоочистки 655 человек»; также «в порядке самоочистки» в 1935 г. был исключен 51 человек (РГАСПИ, ф. 495, оп. 16, д. 61, л. 159). В 1934 г. принято в ряды ТНРП было только 73 человека, а исключен из партии 141. На следующем, III пленуме ЦК ТНРП было отмечено, что многие руководители партячеек указание ЦК «о сокращении пустой, общей писанины и ни к чему не приводящих трескучих собраний» и призыв заняться повседневной работой среди масс не поняли и не то что не усилили такую работу, но даже прекратили созыв партийных собраний (РГАСПИ, ф. 495, оп. 16, д. 61, л. 13). В то же время высшее руководство Тувы не сменилось, премьер-министром с 1929 по 1938 г. оставался С. Чурмит-Тажы. С. К. Тока стал 1-м секретарем ЦК ТНРП в марте 1932 г. и находился на этой должности до осени 1939 г., когда стал генеральным секретарем ТНРП.

VIII Великий хурал (22 июня - 2 июля 1935 г.) призвал правительство ТНР вести аратские массы на борьбу за выкорчевывание корней феодальных отношений в стране, за поднятие производительных сил на основе частной и общественной инициативы аратов, за поднятие культуры, на решительную борьбу с врагами революции и подготовку условий для постепенного перехода на путь некапиталистического развития ${ }^{5}$. Во время работы X съезда ТНРП (1-11.11.1936) повторялся месседж, что правительство является признанным руководителем всей политической, экономической и культурной жизни страны. В то же время подчеркивалось, что ЦК ТНРП, непосредственно не вмешиваясь в функции государственного управления страной, сохраняет руководящую, политическую роль, осуществляемую через членов ТНРП, работающих в госорганах, и обеспечивает через своих

${ }^{1}$ ПБ - Политбюро ЦК ВКП(б); имеется в виду вышеупомянутое совместное постановление ИККИ и ЦК ВКП(б) с осуждением «левого уклона», принятое 29 мая 1932 г.

${ }^{2}$ Больше о новом курсе см.: Резолюции VIII Великого хурала ТНР, 21 июня - 2 июля 1935 г. Kьzьl : Cogaal komitedi, 1936. C. $46-48$.

${ }^{3}$ АРП - Аратская революционная партия.

${ }^{4}$ РСМ, ревсомол - Революционный союз молодежи.

${ }_{5}^{5}$ Резолюции VIII Великого хурала ТНР, 21 июня - 2 июля 1935 г. Кьzьl : Cogaal komitedi, 1936. С. 19. 
членов такую линию в работе государственных, хозяйственных и общественных организаций, которая соответствует решениям съездов и центральных органов партии. В этих целях ЦК обсуждает и принимает решения по важнейшим вопросам политического, хозяйственного и культурного строительства страны ${ }^{1}$. Аналогичные месседжи содержались и в Уставе ТНРП, рассмотренным за месяц до того Монгольской комиссией ЦК ВКП(б) (РГАСПИ, ф. 508. оп. 3, д. 15, л. 6-7), а также в Уставе МНРП, рассмотренным той же комиссией в июле 1935 г. (РГАСПИ, ф. 508, оп. 3, д. 14, л. 77-78). ХІ съезд ТНРП (1-6 ноября 1939 г.) постановил, что «ТНРП должна распространить свое политическое и руководящее влияние на всю политическую и хозяйственную жизнь ТНР» (История Тувы, 2007: 197, 360). А в Программе ТНРП 1941 г. правительство уже не упоминается вообще 2

Исходя из вышесказанного, современные тувинские историки настаивают, что секретарь ЦК ТНРП С. Тока в 1930-е гг. не имел «неограниченного доступа к рычагам управления страной», поскольку партия была объявлена первым помощником правительства (Салчак Тока, 2015: 484). Лишь в Конституции 1941 г. ТНРП была признана ведущей политической силой общества ${ }^{3}$ и тогда Тока, избранный осенью 1939 г. генеральным секретарем ЦК ТНРП, стал фактическим руководителем государства. «Ни о каком культе личности С. К. Тока, сложившемся до того <...> говорить не приходится» (там же: 484). В то же время признается, что налицо была ситуация двоевластия: правительство пыталось оставить за собой авангардную роль, а партия на нее активно претендовала (там же: 140) и при поддержке ВКП(б) и Коминтерна постепенно возвращала утраченные позиции, ее статус руководящей и направляющей силы общества, начиная с 1935 г., стал восстанавливаться и доминирующую роль в политической системе страны снова начал играть Президиум ЦК ТНРП (История Тувы, 2007: 197, 202). Борьба партии с правительством и хуралами за власть была одной из причин политических репрессий в Туве (там же: 197-198).

Итак, возникают сомнения, что при наличии такого амбициозного партийного лидера как С. Тока, к тому же пользовавшегося существенной советской поддержкой благодаря своей абсолютной лояльности к СССР, роль Малого Хурала и правительства ТНР в 1930-е гг. существенно укрепилась. Действительная обстановка в политических кругах ТНР того времени становится ясной из дипломатической переписки. Так, 9 декабря 1935 г. заместитеть наркома иностранных дел СССР Б. С. Стомоняков писал полпреду в Туве В. В. Малкову:

«С этой почтой посылаем Вам записи бесед - моей и т. Борисова с Чурмит-Тажы. Я хочу обратить ваше внимание на главный вопрос, поставленный в этих беседах Чурмит-Тажы, - о взаимоотношениях в руководстве <...> Чурмит-Тажы же рассказал нам о самом возмутительном диктате, ущемлениях и дискредитации правительства, отдельных министров и вообе руководящих работников, что практикуется кутвянским большинством Президиума ЦК партии, в частности, председателем ЦК Токою. У нас нет никаких оснований сомневаться в правильности информации Чурмит-Тажы <... Тем не менее, мы считаем, что установленный такой режим, когда председатель правительства или министр не может поехать в командировку в худон или назначить на работу рядового работника без предварительной санкции ЦК; когда проводится ни чем не обоснованная переброска на низовую работу людей, назначенных на работу хуралом; когда члены партии привлекаются к ответственности за то, что при личной встрече осмеливаются говорить между собой по вопросам партработы; когда членам партии запрещается встречаться с бывшими лишенцами, восстановленными в правах в порядке исправления левацких загибов, - все эти факты не должны были оставаться незамеченными ...»

Исходя даже из последних приведенных фактов, можно сделать вывод, что декларируемая борьба с политической практикой левого уклона в ТНР, мягко говоря, была не до конца последовательной. По видимому, реагируя на подобные обвинения, несомненно, ретранслируемые советской стороной, три месяца спустя, 2 апреля 1936 г. С. Тока пишет Коминтерновскому функционеру О. Куусинену: «ЦК

\footnotetext{
${ }^{1}$ Резолюции Х съезда ТНРП, 1-11 нояб. 1936 г. Кьzьl : ТАР-ньn cogaal komitedi, 1937. С. 46.

${ }^{2}$ Tьba arattın revolustuq namьnьn programь. ARN TK. Кьzьl, 1941. 72 ar.

${ }^{3}$ В Конституции 1941 г. (ст. 82) говорилось про ТНРП как «партию, представляющую собой руководящее ядро всех организаций трудящихся, как общественных, так и государственных». См.: Сборник законов и основных постановлений Правительства Тувинской Народной Республики / под общ. ред. Х. Анчима и С. Т. Чимба. Кызыл: Тувинское государственное издательство, 1944. С. 26.

${ }^{4}$ Цит. по: Байыр-оол М. С. О государственном перевороте 1938 года // ИА «Тува-онлайн». 24.11.2014. URL: https://www.tuvaonline.ru/2014/11/24/repressirovannyy-premer-sat-churmit-tazhy-1894-1938.html (дата обращения: 27.11.2018).
} 
ТНРП информирует Востсекретариат ИККИ, что взаимоотношение и взаимное понимание своей роли и работы в стране между руководителями партии и правительства ВПОЛНЕ НОРМАЛЬНО. Никаких трений, разногласий по принципиальной линии и практической работе, нет» (РГАСПИ, ф. 495, оп. 16, д. 62, л. 48; прописными написано в документе. - И. О.).

Также обращает на себя внимание, к примеру, такой факт. Именно Президиум ЦК ТНРП на своих заседаниях, от своего имени выдвигал кандидатуры претендентов на министерские должности, на главу Тувинценкоопа, директоров госхозов и т. д. Такой вывод можно сделать из стенограммы заседания Президиума ЦК ТНРП 27 сентября 1935 г. (РГАСПИ, ф. 495, оп. 16, д. 61, л. 56). Хотя, надо отметить, что премьер С. Чурмит-Тажы как член Президиума ЦК ТНРП на этих заседаниях также присутствовал. Во время подобных заседаний решались, к примеру, вопросы введения в денежный оборот тувинской валюты - акши (см.: Постановление Политбюро ЦК ТНРП о проведении в ТНР денежной реформы от 16.09.1933 г.) (РГАСПИ, ф. 495, оп. 153, д. 60, л. 129).

Врядли укреплению исполнительной власти содействовал и судебный процесс над премьер-министром и министром иностранных дел ТНР С. Чурмит-Тажы и председателем Президиума Малого Хурала А.-Т. Хемчик-оолом, которых вместе с другими «заговорщиками» в октябре 1938 г. приговорили к смертной казни. Именно С. Тока на III пленуме ЦК ТНРП 31 августа - 3 сентября 1938 г. выступил с докладом «О ликвидации контрреволюционной группы Чурмит-Дажы, Данчая и других и про усиление партийно-массовой работы»1. Интересно, что в ТНР даже доносы начинались обычно с обращения к первому лицу партии «уважаемый отец» (История Тувы, 2007: 199). Весной 1943 г. советские дипломаты характеризовали С. Току, который «с 1932 года беспрерывно работает 1-м секретарем ЦК ТНРП», как «общепризнанного руководителя партии и правительства» (АВП РФ, ф. 06, оп. 5, п. 31, д. 364, л. 26).

С конца 1930-х гг. все решения ЦК ТНРП стали утверждаться только президиумом Малого хурала, в состав которого входили от 5 до 7 человек (там же), по Конституции 1941 г. - количество увеличивалось до 9 человек. Часто наблюдалось одновременное совмещение должностей одними и теми же людьми из-за отсутствия грамотных и образованных кандидатур (Ондар, 2016: 161).

Как Малый Хурал иногда принимал «нужные» решения, можно проиллюстрировать следующим ярким примером. 1 мая 1943 г. М. Г. Сущевский в своем дневнике писал следующее:

«Опубликовано постановление Малого Хурала ТНР о присвоении Генеральному секретарю ЦК ТНРП т. Тока звания генерал-лейтенанта. Это постановление для многих явилось совершенной неожиданностью, так как Президиум Малого Хурала не собирался, а председателем Малого Хурала является Анчима, жена т. Тока. По существу т. Тока получил воинское звание лишь путем “согласования” с секретарями ЦК (Базырсат, Талганчик и др.), которые никогда в таких случаях не станут возражать» (АВП РФ, ф. 06, оп. 5, п. 31, д. 363, л. 21; см. также: Отрощенко, 2019: 210).

Этот эпизод лишний раз подтверждает, что Президиум Малого Хурала не всегда собирался, чтобы обсудить и решить тот или иной вопрос - нужное решение могло быть просто обнародованным от его имени. Это также свидетельствует и о реальном положении дел: тувинский истеблишмент, пребывая под постоянной угрозой репрессий, не решался противоречить генсеку. Записи о поведении С. Токи в неформальной обстановке во время визита в СССР весной 1943 г. иллюстрируют его отношение, в частности, к членам тувинского правительства, которое сложно назвать уважительным (АВП РФ, ф. 06, оп. 5, п. 31, д. 366, л. 22).

Ч. К. Ламажаа, занимающаяся исследованием тувинских политических элит, пишет, что «в воспоминаниях современников достаточно свидетельств о том, что лица, занимавшие самые высокие посты в тувинском правительстве, лишались должностей и изгонялись из состава элиты (номенклатуры) и даже осуждались, расстреливались, лишь по причине несогласия или сомнений по поводу решений С. К. Токи» (Ламажаa, 2010: 113). Даже советская сторона, вполне довольная преданностью тувинского правителя СССР, признавала, что Тока «излишне самолюбив и самоуверен, обидчив, любит парадность, проявляет склонность к вождизму»² (АВП РФ, ф. 06, оп. 5, п. 31, д. 364, л. 26).

\footnotetext{
${ }^{1}$ Надо отметить, что инициатива ареста Чурмит-Тажы и Хемчик-оола принадлежит советской стороне (больше см.: История Тувы, 2007: 204).

${ }^{2}$ Здесь приводится цитата из «Справки о Тувинской Народной Республике», составленной по материалам 3-го Дальневосточного отдела НКИД и датированной 11 апреля 1943 г. (АВП РФ, ф. 06, оп. 5, п. 31, д. 364, лл. 7-27). В «Справке» содержалась краткая информация об истории и народном хозяйство ТНР, заключительными шли сведения о тувинском политическом истеблишменте, в которых акцентировалось на лояльности тувинской политической элиты и руководства Советскому Союзу.
} 
После присоединения ТНР к СССР в 1944 г. С. Тока стал первым секретарем Тувинского областного комитета ВКП(б) и оставался на высшей партийной должности в Туве до конца жизни (1973 г.).

С осени 1933 г. тувинское руководство следовало новому курсу по рекомендациям, разработанным советской стороной для МНР, в частности, провело некоторое сокращение партийных рядов. Но, по-видимому, ряд провозглашенных нововведений носили декларативный характер, ограничиваясь нужной моменту риторикой. Даже смены высшего политического руководства страны после восстания в Тере-Холе, да и вообще в 1932-1933 гг., не произошло. Складывается впечатление, что в первой половине 1930-х гг. тамошние партийные функционеры всей полноты власти и не теряли, несмотря на риторику о правительстве как о хозяине страны. К концу 1930-х гг. от такой риторики в Туве вообще отказались. В результате 1930-1940-е гг. в ТНР прошли при однозначном доминировании в политической жизни республики секретаря ЦК ТНРП С. К. Токи, несмотря на громкие постулаты официальных государственных и партийных документов того времени.

\section{Политический дискурс и центры власти в МНР и ТНР в 1930-1940-х 22.: сходство и отличие}

Как было подчеркнуто во введении, в политическом развитии обеих народных республик было немало общих тенденций. Эта общность заметна и при изучении процессов, происходивших в 1930-1940-х гг. в монгольской и тувинской политических элитах. В частности:

1. В губительных последствиях «левого уклона» в Монголии и Туве были обвинены правящие народно-революционные партии;

2. В первой половине 1930-х гг. обе народные республики провозгласили переход к новому курсу, ряду экономических и политических мер, которые благотворно повлияли на положение дел в Монголии и Туве;

3. Тогда рекомендации для них разрабатывала Монгольская Комиссия при ЦК ВКП(б) под руководством К. Ворошилова;

4. Обеим политическим элитам, начиная с середины 1932 г., была свойственна риторика о правительстве как хозяине страны и народно-революционной партии как его помощнике;

5. Обе партии в первой половине 1930-х гг. провели сокращение партийных рядов;

6. В то же время и монгольские, и тувинские премьеры были членами Президиумов ЦК и в некотором роде олицетворяли собой партийное руководство.

При этом в политических процессах Монголии и Тувы были и различия. К примеру:

1. В Туве провозглашение нового курса началось более чем на год позже, нежели в МНР, поэтому, «оттепель», даже декларированная, продолжалась меньший период времени;

2. В Туве, в отличие от Монголии, не поменялись ключевые политики в результате событий 1932 г.;

3. В Туву, в отличие от Монголии, и после 1932 г. по-прежнему назначались представители Коминтерна;

4. По вопросам, которые обсуждались на заседаниях ЦК ТНРП, складывается впечатление, что даже в первой половине 1930-х гг. тамошние партийные функционеры полноты власти и не теряли, несмотря на риторику о правительстве как о хозяине страны. В МНР в этот период партийные лидеры отступили на второй план и в целом сдерживали свои амбиции.

5. Тогда как в МНР премьерам (в первую очередь Х. Чойбалсану, в меньшей степени и на меньший срок П. Гэндэну) удавалось удерживать в своих руках бразды правления, не уступая партийным функционерам, то в Туве, наоборот, полную победу одержал 1-й секретарь ЦК ТНРП.

\section{Заключение}

По мнению автора, во-первых, такой результат политической борьбы в той или другой республике во многом зависел от силы характера персоналий, оказавшихся на вершине власти. Кто оказывался сильней в политической борьбе, а также смог заручиться большей поддержкой северного соседа премьер или генсек?

Во-вторых, возможно, в МНР удалось временно потеснить всесильных партийных секретарей еще и потому, что Монголия в полной мере ощутила последствия продолжительного восстания 1932 г. Оно 
было не только примером яркого народного сопротивления и выражением огромного недовольства общества, истощенного политикой «левых». Восстание стало ударом и вызовом и для монгольской политической элиты, которая напрямую столкнулась с разрушительными последствиями левого курса: попытками форсированной коллективизации, бегством населения за границу, угрозой своей власти и жизни. Такое общественное потрясение, похоже, на протяжении ряда лет служило сдерживающим фактором для монгольской партийной номенклатуры.

В Туве же восстание 1932 г. было не настолько резонансным, тувинская власть его с относительной легкостью подавила, серьезных политических последствий для правящей элиты оно не сулило. Возможные «нежелательные последствия» тех или иных политических процессов Президиум ЦК ТНРП тогда видел не в событиях собственной истории, а на монгольском примере: «(события в МНР в 1932 г.)» (РГАСПИ, ф. 495, оп. 153, д. 66, л. 20).

В-третьих, в разных политических сценариях для обеих республик сыграл свою роль и тот факт, что в Туву, в отличие от Монголии, и после 1932 г. по-прежнему назначались представители Коминтерна, что еще более подогревало левые настроения и стремление к доминантному партийному диктату тогдашнего, всецело ориентированного на СССР и Коминтерн, высшего тувинского руководства.

B-четвертых, решающим фактором в этих процессах также являлась степень советской поддержки того или иного политика, базировавшаяся, в первую очередь, на лояльности последнего к СССР. Хотя советская сторона и внимательно следила за укреплением «народно-революционных» партий в обеих республиках, это не значило, что в острой политической борьбе, имевшей место в Монголии и Туве, она автоматически поддерживала именно партийных функционеров. Москва внимательно наблюдала за популярностью тех или иных политиков, их лояльностью, оценивала, кто и насколько соответствует ее интересам.

\section{СПИСОК ЛИТЕРАТУРЫ}

Баабар (2010) История Монголии: от мирового господства до советского сателлита. Казань : Татарское книжное изд-во. 542 с.

История Монголии. ХХ век (2007) / отв. ред. Г. С. Яскина. М. : ИВ РАН. 448 стр.

История Тувы (2007) / под ред. В. А. Ламина. Новосибирск : Наука. Т. ІІ. 430 с.

Кузьмин С. Л., Оюунчимэг Ж. (2015) Вооруженное восстание в Монголии в 1932 г. М. : ООО «Издательство МБА». $212 \mathrm{c}$.

Ламажаа, Ч. К. (2010) Клановость в политике регионов России. Тувинские правители. СПб. : Алетейя. 208 с.

Надиров, Ш. Г. (1995) Цеденбал. 1984 год. М. : Восточная литература. 190 с.

Ондар, Е. М. (2016) К вопросу об особенностях политического развития Тувинской Народной Республики в 1920-1930-е годы // Вестник Томского государственного педагогического университета. № 12 (177). С. 158-164.

Отрощенко, І. В. (2010) «...Він живе цією ідеєю»: панмонгольський вектор Х. Чойбалсана // Східний світ. № 3. С. 81-91. (На укр. яз.).

Отрощенко, И. В. (2019) Тувинская Народная Республика накануне вхождения в состав СССР глазами советского дипломата // Новые исследования Тувы. № 4. С. 207-215. DOI: https://doi.org/10.25178/nit.2019.4.17

Отрощенко, І. В. (2021) Колективне керівництво та боротьба за владу в МНР 1950-х рр.: Ю. Цеденбал і Д. Дамба // Східний світ. № 1. С. 5-17. (На укр. яз.). DOI: https://doi.org/10.15407/orientw2021.01.005

Рощин, С. К. (2005) Маршал Монголии Х. Чойбалсан. Штрихи биографии. М. : ИВ РАН. 158 с.

Рощин, С. К. (2008) П. Гэндэн, монгольский национальный лидер. Штрихи биографии. М. : ИВ РАН. 160 с.

Салчак Тока (2015) / У. А. Донгак и др.; под общ. ред. С. К. Шойгу и др. М. : Слово. 544 с.

Самдан, А. А. (2020) Вооруженное восстание в Туве в 1930 г. // Новые исследования Тувы. № 3. С. 66-80. DOI: www.doi.org/10.25178/nit.2020.3.5

Шинкарев, Л. И. (2006) Цеденбал и его время: в 2 т. М. : Собрание. Т. 1: Любовь. Власть. Трагедия. 496 с.

Atwood, C. P. (1999) Sino-Soviet Diplomacy and the Second Partition of Mongolia, 1945-1946// Mongolia in the Twentieth Century: Landlocked Cosmopolitan. Edited by Stephen Kotkin and Bruce A. Elleman. New York and London : M. E. Sharpe. P. 137-161.

Atwood, C. P. (2004) Encyclopedia of Mongolia and the Mongol empire. N.Y. : Facts on File. 678 p.

Christian, D. (2018) A History of Russia, Central Asia and Mongolia. Vol. II: Inner Eurasia from the Mongol Empire to Today, 1260-2000. Wiley-Blackwell. 656 p. DOI: https://doi.org/10.1002/9781119392606 
Dillon, M. (2020) Mongolia: a political history of the land and its people. London : Bloomsbury I. B. Tauris, viii+224 p.

Myadar, O. (2017) In the Soviet Shadow. Soviet Colonial Politics in Mongolia // Inner Asia. Vol. 19. Issue 1. Pp. 5-28. DOI: https://doi.org/10.1163/22105018-12340077

Radchenko, S. (2012) Carving up the Steppes: Borders, Territory and Nationalism in Mongolia, 1943-1949 // Eurasia Border Review, Vol. 3, Special Issue, pp. 9-31.

Socialist Devotees and Dissenters: Three Twentieth-Century Mongolian Leaders (2011) / Interviews conducted by Yuki Konagaya and I. Lkhagvasuren, Translated by M. Rossabi, edited and compiled by M. Rossabi. Osaka : National Museum of Ethnology. 298 p.

Stolberg, E.-M. (1997) Stalin und die chinesischen Kommunisten 1945-1953: Eine Studie zur Entstehungsgeschichte der sowjetisch-chinesischen Allianz vor dem Hintergrund des Kalten Krieges. Stuttgart : Steiner. 327 s.

Szalontai, B. (2005) Tsedenbal's Mongolia and Communist Aid Donors: A Reappraisal // The Mongolian Journal of International Affairs. No. 12. P. 91-95. DOI: https://doi.org/10.5564/mjia.v0i12.97

Дата поступления: 12.06.2021 2.

\section{REFERENCES}

Baabar (2010) Istoriia Mongolii: ot mirovogo gospodstva do sovetskogo satellita [A History of Mongolia: from global domination to the Soviet satellite]. Kazan, Tatarskoe knizhnoe izd-vo. 542 p. (In Russ.).

Istoriia Mongolii. XX vek [The History of Mongolia in the 20 $0^{\text {th }}$ century] (2007), ed. by G. S. Yaskina. Moscow, IV RAN. 448 p. (In Russ.).

Istoriia Tuvy [The History of Tuva] (2007): in 3 vols. / ed. by V. A. Lamina. Novosibirsk, Nauka. Vol. 2. 430 p. (In Russ.).

Kuz'min, S. L. and Oiuunchimeg, Zh. (2015) Vooruzhennoe vosstanie v Mongolii v 1932 g. [The armed uprising in Mongolia, 1932]. Moscow, OOO “Izdatel'stvo MBA”. 212 p. (In Russ.).

Lamazhaa, Ch. K. (2010) Klanovost'v politike regionov Rossii. Tuvinskie praviteli [The clan politics of Russia's regions: The Leaders of Tuva]. St. Petersburg, Aleteiia. 208 p. (In Russ.).

Nadirov, Sh. G. (1995) Tsedenbal. 1984 god [Tsedenbal. The year 1984]. Moscow, Vostochnaia literatura. 190 p. (In Russ.).

Ondar, E. M. (2016) K voprosu ob osobennostiakh politicheskogo razvitiia Tuvinskoi Narodnoi Respubliki v 1920-1930e gody [On the political development of the Tuvan People's Republic in the 1920-1930s]. Vestnik Tomskogo gosudarstvennogo pedagogicheskogo universiteta, no. 12 (177), pp. 158-164. (In Russ.).

Otroshchenko, I. V. (2010) ‘...Vin zhive tsieiu ideeiu’: panmongol’s'kii vektor Kh. Choibalsana ['...He lives by this idea’: a pan-Mongolian aspect in the policy of Kh. Choibalsan]. Shidnij svit, no. 3, pp. 81-91. (In Ukr.).

Otroshchenko, I. V. (2019) Tuvinskaia Narodnaia Respublika nakanune vkhozhdeniia v sostav SSSR glazami sovetskogo diplomata [Tuvan People's Republic on the eve of accession to the USSR through the eyes of a Soviet diplomat]. New Research of Tuva, no. 4, pp. 207-215 (In Russ.). DOI: https://doi.org/10.25178/nit.2019.4.17

Otroshenko, I. V. (2021) Kolektyvne kerivnytstvo ta borot'ba za vladu v MNR 1950-kh rr.: Yu. Tsedenbal i D. Damba [Collective leadership and the struggle for power in the Mongolian People's Republic in the 1950s: Yu. Tsedenbal and D. Damba]. Shìdnij svit, no. 1, pp. 5-17. (In Ukr.). DOI: https://doi.org/10.15407/orientw2021.01.005

Roshchin, S. K. (2005) Marshal Mongolii Kh. Choibalsan. Shtrikhi biografii [The Marshal of Mongolia Kh. Choibalsan: Notes towards a biography]. Moscow, IV RAN. 158 p. (In Russ.).

Roshchin, S. K. (2008) P. Genden, mongol'skii natsional'nyi lider. Shtrikhi biografii [P. Genden, Mongolian national leader. Notes towards a biography]. Moscow, IV RAN. 160 p. (In Russ.).

Salchak Toka (2015) Ed. by S. K. Shoigu at al. Moscow, Slovo. 544 p. (In Russ.).

Samdan A. A. (2020) Vooruzhennoe vosstanie v Tuve v 1930 g. [Tuvan armed uprising in 1930]. New Research of Tuva, no. 3, pp. 66-80. (In Russ.). DOI: www.doi.org/10.25178/nit.2020.3.5

Shinkarev, L. I. (2006) Tsedenbal i ego vremia [Tsedenbal and his time]: in 2 vols. Moscow, Sobranie. Vol. 1: Liubov'. Vlast'. Tragediia [Love. Power. Tragedy]. 496 p. (In Russ.).

Atwood, C. P. (1999) Sino-Soviet Diplomacy and the Second Partition of Mongolia, 1945-1946. In: Mongolia in the Twentieth Century: Landlocked Cosmopolitan. Ed. by S. Kotkin and B. A. Elleman. New York, London, M. E. Sharpe. Pp. 137-161.

Atwood, C. P. (2004) Encyclopedia of Mongolia and the Mongol empire. New York, Facts on File. 678 p. 
Christian, D. (2018) A History of Russia, Central Asia and Mongolia. Vol. II: Inner Eurasia from the Mongol Empire to Today, 1260-2000. Wiley-Blackwell. 656 p. DOI: https://doi.org/10.1002/9781119392606

Dillon, Michael (2020) Mongolia: a political history of the land and its people. London, Bloomsbury I. B. Tauris. viii+224 p.

Myadar, O. (2017) In the Soviet Shadow. Soviet Colonial Politics in Mongolia. Inner Asia, vol. 19, issue 1, pp. 5-28. DOI: https://doi.org/10.1163/22105018-12340077

Radchenko, S. (2012) Carving up the Steppes: Borders, Territory and Nationalism in Mongolia, 1943-1949. Eurasia Border Review, vol. 3, special issue, pp. 9-31.

Socialist Devotees and Dissenters: Three Twentieth-Century Mongolian Leaders (2011). Interviews conducted by Yu. Konagaya and I. Lkhagvasuren, Translated by M. Rossabi, edited and compiled by M. Rossabi. Osaka, National Museum of Ethnology. 298 p.

Stolberg, E.-M. (1997) Stalin und die chinesischen Kommunisten 1945-1953: Eine Studie zur Entstehungsgeschichte der sowjetisch-chinesischen Allianz vor dem Hintergrund des Kalten Krieges. Stuttgart, Steiner. 327 s.

Szalontai, B. (2005), Tsedenbal's Mongolia and the Communist Aid Donors: A Reappraisal. The Mongolian Journal of International Affairs, no. 12, pp. 91-95. DOI: https://doi.org/10.5564/mjia.v0i12.97

Submission date: 12.06.2021. 